\title{
An Empirical Analysis on the Determinants of Foreign Subsidiary's Local Embeddedness: Focusing on Korean MNCs in China*
}

\author{
Byoung-Goo KIM ${ }^{1}$, Gyu-Bae KIM ${ }^{2}$ \\ Received: June 02, 2019 Revised: November 01, 2019 Accepted: November 15, 2019
}

\begin{abstract}
The purpose of this paper is to empirically analyze the determinants of foreign subsidiary's local embeddedness because it is critically important for the subsidiary to build a variegated local network. This paper suggests that a MNC's global capability, the degree of autonomy granted by the headquarters of the multinational corporation to its foreign subsidiary, the foreign subsidiary's absorptive capacity based on local environment, and its level of localization will affect the subsidiary's local network embeddedness. The empirical analysis confirmed that when the headquarters gives the foreign subsidiary more autonomy, this has a positive effect on the local embeddedness of the foreign subsidiary and when the foreign subsidiary has a strong absorptive capacity, this has a positive correlation with the local embeddedness of the foreign subsidiary. And this paper found that when the foreign subsidiary has achieved a high level of staff localization, this foreign subsidiary will have a higher level of local embeddedness. This study identified the preceding conditions necessary for a foreign subsidiary of a multinational corporation to effectively embed itself in the local network by analyzing factors related to the multinational corporation's headquarters and subsidiaries, and thus contributes significantly to continued research on the local embeddedness of subsidiaries.
\end{abstract}

Keywords : MNC, Foreign Subsidiary, Local Embeddedness, China

JEL Classification Code : L10, F20, F23

\section{Introduction}

In cases where multinational corporations face a variety of uncertainties in the external environment as they enter overseas markets, they generally tend to rely on the firm's internal organization (Prahalad \& Doz, 1987), or adopt the strategy of leading the formation of internal and external networks. The subsidiaries of multinational corporations usually have an external network in the local site, and this distinct network which subsidiaries to which have access expose them to various opportunities opened by new

* This research was supported by the Daejeon University Research Grants 2016.

1 First Author, Associate Professor, Division of Global Business, Hanshin University, South Korea. Email: bgkim@hs.ac.kr

2 Corresponding Author, Associate Professor, Department of Business Administration, Daejeon University, South Korea. Email: gbkim@dju.ac.kr

(c) Copyright: Korean Distribution Science Association (KODISA)

This is an Open Access article distributed under the terms of the Creative Commons Attribution Non-Commercial License (http://Creativecommons.org/licenses/by-nc/4.0/) which permits unrestricted noncommercial use, distribution, and reproduction in any medium, provided the original work is properly cited. knowledge or ideas. Also, the network formed around the subsidiary gives it easier access to a wide range of network resources circulating in the network, and this strengthens subsidiary's competitiveness in the market and furthermore, may lead to the enhanced competitiveness in each of the other subsidiaries, resulting in improving the overall competitiveness of the multinational corporation (Anderson et al., 2002). Therefore, one of the critically important tasks of a foreign subsidiary is to become embedded in the local network consisting of various types of suppliers and clients, thereby building a high level of relation capital.

A multinational corporation consists of a single whole network not only including the country in which the headquarters is located but also involving other countries that participate in the corporation's differentiated subsidiaries. Also, each subsidiary engages in business activities within an external network consisting of suppliers, buyers, competitors and various other actors in the country or region in which it is located. From this perspective, when analyzing the performance and characteristics of a subsidiary, it is necessary to take account of the influence of 
each of the actors that form its external network in addition to examining the headquarters and the subsidiary itself. Recently, many studies on multinational corporations and their subsidiaries have actively focused on the importance of the external network of foreign subsidiaries (Andersson et al, 2001, 2002; Birkinshaw et al, 1998; Ciabuschi et al., 2014; Martynovich, 2017; Joseph et al., 2016; Wei, 2015). Previous studies have demonstrated that the degree of local embeddedness of the foreign subsidiary has a positive effect on improving the subsidiary's performance or level of knowledge creation. However, it is hard to find any studies that identify the antecedent factors that directly affect network embeddedness, which has such a strong impact on a subsidiary's performance. To address this shortcoming in existing studies, this study analyzes how the relationship factors between headquarters and subsidiaries and their subsidiaries' factors affect the local network embeddedness.

This study proposes that a MNC's global capability, the degree of autonomy granted by the headquarters of the multinational corporation to its foreign subsidiary, the subsidiary's absorptive capacity based on local environment, and its level of localization will affect the subsidiary's local network embeddedness.

Based on this view, the following research questions were asked:

- Does the global capabilities of multinational companies affect the local network embeddedness of their subsidiaries?

- Does the degree of foreign subsidiaries' autonomy granted by the headquarters influence the local network embeddedness?

- Does the subsidiary's absorption capacity and degree of localization influence its local embeddedness?

This paper is organized as follows. Part 2 will begin with a theoretical discussion of network embeddedness and then build on preceding studies on the local embeddedness of overseas subsidiaries to present a research model and derive a set of hypotheses. Part 3 will describe the composition of the sample and explain the measurement of variables and the statistical analysis model that will be used to verify our hypotheses. Part 4 will present the results of our empirical analysis, and the last part will summarize the findings of this study and discuss their implications.

\section{Literature Review and Hypotheses Development}

\subsection{Conceptual Definition and Types of Network Embeddedness}

In network theory, all organizations are regarded as embedded in a network of linkages that influence each activity and its outcomes. Embeddedness is a concept that emphasizes the characteristics of relations among different actors, based on the basic principle that an actor exchanges mutual influence with other actors within the structure of the specific relations formed among them (Granovetter, 1985).

This means that the behavior of an individual actor that exist in a specific structure of relations with other actors cannot be interpreted independently without considering these relations; the concept explains that the specific mutual relations existing among these respective actors will influence their behavior. Researchers such as Granovetter (1992) and Grabher (1993), whose key focus is the linkages and relations among actors, conceptualized network embeddedness to explain the phenomenon that the economic behavior of actors in a network and the outcomes of this behavior is affected by or determined by the narrow dyadic relation that exists between them as well as by the broader network structure composed by these relations. In the same vein, Jones et al. (1997) and Dayashindhu (2001) defined embeddedness as the phenomenon of how economic behavior is influenced by the dyadic relation among the elements that constitute an industry as well as by the structure of the whole network, and the process by which such behavior is continually formed by the relations among these differing components.

Embeddedness, which points to how the behavior of an individual actor is affected by the relations among the component actors within a network and by the relational structure, can be understood based on specific attributes such as mutual influence, dependency, connectedness and mutual adaptation (Liao, 2015). Scholars explain that embeddedness can also be understood in terms of the specific transactions or exchange logic caused by the network structure; they argue that embeddedness provides new opportunities, enables corporations to design products and achieve production levels to better meet the preferences of customers, and allows the corporation to have a clearer understanding of each of the other network actors and form a configuration with them.

The corporation is necessarily embedded in a network of social, professional and transactional relations with other organizations, and this network not only encompasses suppliers, clients and competitors but also constitutes a series of vertical and horizontal relational systems with other organizations, transcending the boundaries of an industry or a country. Each component organization is influenced by its embeddedness within the given network (Gulati, 1998). Furthermore, embeddedness provides information regarding opportunities for connecting with other actors or exercises a positive effect on the formation of such linkages (Ahuja, 2000). The economic behavior of a corporation can thus be explained by the influence of the relations the corporation has within its network and the constitution of the network to which the corporation is linked; in other words, the behavior is affected by the corporation's embeddedness and the network structure. 
Scholars in the field of international business management explain network embeddedness as the phenomenon wherein the individual and overall relations formed by the respective actors that constitutes a network and the structure of interactive relations among these actors have influence on decisions regarding the various behaviors of a subsidiary, the actual implementation of activities and the outcome of each behavior, and they thus analyze the network embeddedness of a multinational corporation's subsidiary(Kim, 2018). A multinational corporation can be described as an internal network comprised of the headquarters and each of its subsidiaries, and it can be observed that each subsidiary also forms a unique network in the country where it is located.

An internal network refers to the linkages between the headquarters and its subsidiaries, which is a corporate network. It is emphasized when examining the overall integration and configuration of the multinational corporation. By contrast, in the case of an external network, the focal unit is the mode of linkages with actors in an external domain (Tichy, Tushman \& Fomburn, 1979). A subsidiary of a multinational corporation is embedded in a distinct external network comprised of differing actors such as suppliers, clients, and competitors, and the subsidiary forms relations of actual or potential transactions or exchanges with these other actors.

Embeddedness can be classified into the following types: temporal embeddedness, spatial embeddedness, political embeddedness, market embeddedness, social embeddedness, and technological embeddedness. In the case of temporal embeddedness, the corporate network is regarded as essentially a socio-economic system that evolves over time, embedded not only in natural time but also in a social temporal structure. Spatial embeddedness is a concept that emphasizes the role of space and geography in a corporate network; spatial embeddedness is used to explain where corporate activities are located and how they are organized. Market embeddedness reflects the view that all corporations are embedded in a particular market and that a corporation is connected to other clients, suppliers, distributors, and competing businesses through strategic partnerships. Social embeddedness explains that a corporate network is embedded in a variety of social structures. The concept illuminates the fact that interactions between an individual employee and the group results in learning, technology transfers, and the generation of power structures and that individual members can generate their own contact network. Technological embeddedness points out that a corporation is embedded in various technological systems, and that at the corporate and social level, the corporation is embedded in the development of such systems. Furthermore, the corporation is influenced by infrastructural technology and engages in strategic partnerships with the network comprised of other corporations, research institutes, universities and scientific research complexes (Halien \& Tornroos, 1998).

\subsection{The local embeddedness of foreign subsidiaries}

For a foreign subsidiary of a multinational corporation to succeed in conducting business with ease and stability in the country where it is located, where the business environment differs from that of the home country, it is critically important for the subsidiary to build a variegated local network. The most significant characteristics of a multinational corporation is that its foreign subsidiaries are each closely linked to the networks within the local country. The networks in the local country have idiosyncratic patterns and can generate new knowledge or offer business opportunities (McEvily \& Zaheer, 1999). For a foreign subsidiary, local embeddedness means positioning itself as an actor in a network comprised of various stakeholders in the local market (for example, governmental institutions, suppliers, distributors, competitors, and consumers) (Andersson et al., 2001).

A subsidiary that is deeply embedded in the local business network is able to absorb existing technologies and develop new ones (Ahuja, 2000; Cohen and Levinthal, 1990) while also reducing the level of environmental threats (Miner, Amburgey \& Stearns, 1990). The embeddedness also has a positive effect on gaining competitive superiority (Andersson et al., 2002), empowering the subsidiary to achieve strong business performance (Baum \& Oliver, 1991; Hagedoorn \& Schakenraad, 1994). Andersson et al. (2002) claimed that the external network formed by the subsidiary contributes to the competitive superiority of the multinational corporation in two ways. First, the subsidiary acquires resources that can only be obtained through the business network in the local country and therefore gains competitive superiority. Secondly, the resources or capabilities that the subsidiary obtains through the external network may be transferred to the headquarters or to other subsidiaries, and thereby strengthen the overall capabilities of the multinational corporation. Therefore, when a foreign subsidiary is deeply embedded in the local country's business network, it becomes able to easily exchange technological capabilities or know-how that are otherwise difficult to exchange in the market and are challenging to find inside the corporation and boosts its ability to gain new knowledge and acquire and transfer technologies (Powell, 1990).

Summarizing the above, we can conclude that embeddedness in a local network allows the foreign subsidiary to efficiently acquire information and knowledge and engage in long-lasting cooperative relations with various organization in the network, which may result in shared understanding and expectations regarding the business strategies or work methods to adopt in response to internal and external challenges (Dore, 1992; Powell, 1990).

For overseas subsidiaries, local embeddedness means positioning as an actor within a network of various stakeholders (e.g., government agencies, suppliers, 
distributors, competitors, consumers, etc.) in the local market (Andersson et al., 2001). Through this local embeddedness, the foreign subsidiary can accumulate business assets, knowledge, and know-how that equips it to adapt to conditions in the local environment. Furthermore, these business resources can be effectively transferred to other subsidiaries or to the headquarters, which ultimately results in improving the competitiveness of the multinational corporation as a whole (Kogut \& Zander, 1993).

\subsection{Autonomy between Headquarter and Subsidiary and Local Embeddedness}

A multinational corporation must simultaneously achieve global integration and local responsiveness, which may seem to be two contradictory objectives (Doz \& Prahalad, 1984). To address this issue, many scholars in the field of international business management have focused their attention on how the level of control exercised by the multinational corporation's headquarters on its foreign subsidiary functions as a means of coordinating the strategies for global integration and local responsiveness (Doz et al., 1981; Gate \& Egelhoff, 1986). From the perspective of the headquarters of a multinational corporation, many subsidiaries are geographically and culturally distant from the headquarters, and therefore the issue of how strongly it should control these subsidiaries is directly tied to the issue of what to prioritize in each subsidiary, given the divergent environmental pressures of global integration and local responsiveness (Gate \& Egelhoff, 1986).

Generally, when the headquarters maintains strong control over its foreign subsidiary, this will facilitate the transfer of resources and knowledge held by the headquarters (Egelhoff, 1988; Gupta \& Govindarajan, 2000) but excessive control over the foreign subsidiary will restrict the latter's ability to learn knowledge and accumulate experience locally, which can have an negative effect on the growth of the subsidiary, and consequently, the excessive control may impede the subsidiary's efforts to generate new knowledge in the local country (Birkinshaw et al., 1998; Yan, 2000).

Therefore, when the headquarters imposes a high degree of control, the subsidiary may find it difficult to explore and experiment freely and may be deterred from forming a new network in the local market. Moreover, the foreign subsidiary ought to actively explore and experiment in the local network to reduce cost of foreignness, but strong control from its headquarters may negatively influence the learning motivation and experimental initiative of the subsidiary (Bartlett \& Ghoshal, 1989; Frost et al., 2002). According to this logic, when the headquarters exercises a strong level of control, the subsidiary at the local site may be obstructed from actively pursuing local business activities, and furthermore, the control may also be a negative factor preventing the building of a local network. Based on these views, we established the following hypothesis.

Hypothesis 1: The higher the autonomy to a foreign subsidiary of the headquarter, the more positively it will have an impact on the local embeddedness of its overseas subsidiary.

\subsection{The Global Capabilities of the Headquarters and Local Embeddedness}

The relation between the headquarters and subsidiary of a multinational corporation can be examined from a capability-based view. From a capability-based view, it has been argued that because multinational corporations each have varying capabilities, they will mutually influence the upcoming investment and management decisions of other corporations situated in the same external environment (Song, 2002). This analysis is closely related to the experiential learning view, which argues that the management experience gained by the multinational corporation in a foreign market may influence its future investment behavior.

A multinational corporation expands its range of experience and its network as it performs production and business activities various foreign countries and thereby builds its global capabilities. These global capabilities include both the ability of the headquarters to integrate its own technologies, products, and information through the global network and the ability to transfer the generated knowledge and resources to its overseas subsidiaries, enabling them to efficiently conduct business in a foreign locality. The core of these global capabilities is experience in internationalizing the headquarters' resources in various foreign markets (Gupta \& Govindarajan, 1991).

When the headquarters has a high level of global capabilities, it prioritizes the goal of enabling its overseas subsidiaries to utilize these capabilities offered by the headquarters to achieve global integration and efficiency. This is because the main task of the headquarters of a multinational corporation is to integrate the capabilities accumulated locally by the subsidiaries in various foreign countries and to promote an efficient configuration between the headquarters and its subsidiaries. Therefore, if the multinational corporation has a lot of internationalization experience in various foreign markets, it is highly likely that this will negatively influence the subsidiaries' willingness to pursue business activities independently. In other words, the subsidiaries may lose the motivation to actively interact with the various local networks. As described above, when the headquarters has strong global capabilities, it becomes less probable that the subsidiary will form relations and business activities within the local network with active initiative. Therefore, we formulated the following hypothesis. 
Hypothesis 2: The higher the level of global capabilities of headquarters, the more negatively it will have an impact on the local embeddedness of its overseas subsidiary.

\subsection{Absorptive Capacity of the Subsidiary and Local Embeddedness}

Absorptive capacity refers to the ability to identify the value of new external information and absorb and utilize the information for business purposes (Cohen \& Levinthal, 1990). Such knowledge absorptive capacity affects the knowledge accumulation of a corporation and simultaneously affects the knowledge flow that is necessary to improve the corporation's performance. When the corporation has strong absorptive capacity, it will actively respond to conditions and information in the external environment and equip itself with more capabilities, which enables it to identify and utilize useful external information.

Gupta and Govindarajan (2000) argued that a subsidiary's knowledge flow has significant correlation with the variety of means of transfer, the motivation for knowledge acquisition, and its absorptive capacity for transferred knowledge. Among these, the organization's absorptive capacity was argued to be the most important determinant of knowledge transfer in a multinational corporation, having a significant influence in the knowledge flow of a foreign subsidiary. Absorptive capacity not only increases the overall knowledge accumulation of a multinational corporation but may also reduce the research and development cost of its global innovation network. In addition, the efficient transfer of knowledge accelerates the multinational corporation's technology learning to be faster than the competitors' speed of imitation and therefore enhances the innovative capability of the corporation.

Therefore, if the foreign subsidiary has high absorptive capacity, it will identify and internalize valuable knowledge information found in the diversified knowledge flow of the foreign market. Moreover, it will efficiently absorb and digest the knowledge transferred from headquarters. In this process, the subsidiary will become more motivated to actively exchange information with various local networks and will likely strengthen its relations with local networks. Therefore, we established the following hypothesis.

Hypothesis 3: The higher the absorptive capacity of a foreign subsidiary, the more positively it will have an impact on the local embeddedness of its overseas subsidiary.

\subsection{Subsidiary Localization and Local Embeddedness}

The concept of localization was defined by Perlmutter (1969) as the process in which a firm performs major portions of corporate business activities such as production, sales, human resources management, procurement of raw materials, marketing, and R\&D at the local site and succeeds in surviving on its own, thereby establishing itself as a local corporation. Gates and Egelhoff (1986) conceptualized localization as the degree of decision-making authority exercised by a local subsidiary, whereas Rosenzweig and Nohria (1994) defined localization as the degree of similarity to the method of business used by other local corporations. Synthesizing the various references to localization found in preceding studies, we may describe localization as the process in which a corporation engaged in international business activities adapts itself to the different culture or business environment of the foreign country to strengthen its competitive superiority. When a foreign subsidiary undergoes localization, the focus is not on the pressure to achieve global integration based on the powerful configuration and control exercised by the headquarters, but rather on reorganizing the foreign subsidiary's strategic and administrative decision-making process in response to the cultural and environmental characteristics of the locality, to adjust to local conditions. Localization can thus be regarded as one of the most important business activities for reducing the cost of foreignness.

A foreign subsidiary may find it especially difficult to manage human resources. It will experience conflicts if it fails to understand local interests and cultural contexts and attempts to simply apply the business methods imported from the home country. The localization of human resources can be achieved by increasing the hire of local, functional labor and the recruitment of locals at the managerial level. In response to increasing demand for employment in the local country, the subsidiary must internationalize its human resources while also responding to the needs of business localization.

Therefore, the localization of human resources should not be limited to simply replacing employees with locals; the subsidiary should simultaneously build a business system customized to the locality and pursue autonomous business endeavors. For this purpose, it must recruit capable local employees and continually foster the development of the capabilities and corporate loyalty of the local staff. A foreign subsidiary that succeeds in achieving a high level of staff localization will more actively form relations with local networks in its business activities and will be able to communicate better with the local stakeholders. Based on these views, we adopted the following hypothesis.

Hypothesis 4: The higher the level of staff localization of overseas subsidiaries, the more positively it will have an impact on the local embeddedness of its overseas subsidiary. 


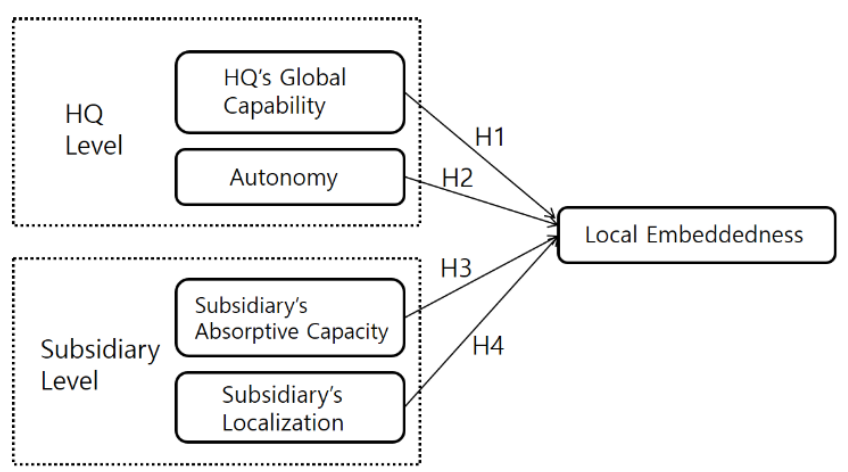

Figure 1: Research Model

\section{Research Method}

\subsection{Research Sample and Data Collection}

The sample analyzed in this research consisted of the subsidiaries of South Korean corporations in China, which were either simultaneously engaged in production and sales activities or were performing a minimum of production activities. For this survey, we used the Directory of Overseas South Korean Corporations in 2016 published by KOTRA (hereinafter referred to as "the Chinese Edition"). When building a sample of South Korean subsidiaries active in China, we excluded firms which had been in production for 2 years or less as of 2018, firms with less than 100 employees, small firms with an investment of 1 million dollars or less, and firms that did not have headquarters in South Korea. We then randomly selected a total of 785 companies for the sample included in this study. The variables related to the hypotheses tested in this study were mostly information on internal corporate organization and management which could not be obtained from secondary data. Therefore, we conducted a survey to measure these variables.

The survey questions were composed with reference to previous studies (Andersson et al., 2002; Dhanaraj et al., 2004; Frost et al., 2002; Gupta \& Govindarajan, 2000; Tsai \& Ghoshal, 1998) and the survey was conducted through various means, including e-mail, fax, and phone. To secure a higher rate of response, we first phoned the targeted corporations to identify an upper-level manager, with whom we spoke over the phone directly to explain the purpose of the study and request cooperation. We tried to conduct the survey with executive-level staff dispatched from South Korea, and if a response from this level was difficult to obtain, we solicited survey responses from director-level managers dispatched from South Korea. A total of 121 response sheets were recovered, representing $15.4 \%$ of the total survey targets. From these, we excluded 7 response sheets that were unfaithfully completed or omitted information, and thus a final total of 114 response sheets was included in the study.

\subsection{Measurement of Variables}

\subsubsection{Dependent Variables}

This study analyzed the embeddedness of a foreign subsidiary in the local network based on the degree to which it interacted with local suppliers or clients and the degree to which it applied the knowledge acquired from various network relations to the practices of the subsidiary, including production, business conventions, product development, etc. To determine the level of local network embeddedness in these terms, it is necessary to not only look at the products and services the firm provides to the local country and but also measurement tools to gauge the firm's adaptative interactions in the local country at various levels, including its internal and external business conventions and internal work procedures. For this purpose, we drew on preceding studies (Andersson \& Forsgren, 2000; Anderson, Forsgren \& Holm, 2002; Sumelius \& Sarala, 2008) to help establish the four items we measured on a 5-point Likert scale, designed to determine the degree to which the subsidiary applied the information on products, technologies, and markets obtained from related local firms (suppliers, major client firms, distributors, etc.) to its own practices, including product development, production method, and standard work procedures. Specifically, the four survey questions intended to measure local embeddedness asked how far the subsidiary incorporated such information to modify its 1) product designs, functions, and specifications, 2) production methods or production processes, 3) general business conventions, and 4) standard work procedures to better respond to the idiosyncratic demands of important suppliers or clients. The response to each question was measured on a 5 -point Likert scale $(1=$ Very Low, $5=$ Very High).

\subsubsection{Independent Variables}

One of the global capabilities of the headquarters is its internationalization experience. Based on preceding studies (Takeuchi, Shay \& Li, 2008; Young \& Tavares, 2004), we measured this by the number of subsidiaries the headquarters had in foreign countries. To measure the level of control exercised by the headquarters over the foreign subsidiary, we referenced preceding studies (Ghoshal, Korine \& Szulanski, 1994; Gates \& Egelhoff, 1986) and modified the decision making items to establish the following six items pertaining to decision making, measured on a 5 -point scale ( $1=$ The decision is made entirely by the headquarters, $3=$ The subsidiary and headquarters have equal influence on the decision, $5=$ The decision is made entirely by the subsidiary). Measured items were presented in in a total of 6 questions, focusing on 1) personnel policies (employee hiring and dismissals, etc.), 2) marketing activities (product advertisement and sales methods, etc.), 3) $\mathrm{R} \& \mathrm{D}$ activities (new product development or introduction of new technologies, etc.), 4) production activities (example: establishment of production plans), 5) financial activities (budget planning, etc.) and 6) improvement or modification 
of existing products. To measure the subsidiary's absorptive capacity, we adopted the definition given by Cohen and Levinthal (1990) and also referenced other preceding studies (Minbaeva et al., 2014) and established four measurement items: the number of employees or experts well informed about China's culture, corporations, and market, the level of education or training programs given to employees related to internal and external corporate matters (Jeong \& Wang, 2016), the willingness of employees to learn new technologies and work-related knowledge, etc. These items were measured on a 5-point Likert scale. Lastly, we calculated the degree of localization of the foreign subsidiary based on the percentage of locals in the managerial staff of the foreign subsidiary (Gong, 2003; Lam $\&$ Yeung, 2010). If the percentage of local managers was high, the foreign subsidiary was regarded as having a higher level of localization compared to those with a lower percentage of locals in the managerial staff.

\subsubsection{Control Variables}

In addition to the independent and dependent variables, we established as the following as control variables for this study: the subsidiary's number of years in business, its foreign market entry mode, industries, and the size of the subsidiary. These control variables were included in the regression analysis model. First, the subsidiary's number of years in business indicates its level of local experience. When the subsidiary has been engaged in local activities for a longer time, this will likely affect its local embeddedness. Secondly, the entry mode may also affect the subsidiary's local embeddedness. In this study, we distinguished between wholly owned entry and joint venture entry. Compared to wholly owned investments, joint venture investments are likely to increase interactions with local networks because of the partner's shares or contracts. In this study, wholly owned investments were set as 1 and joint venture investments were set as 0 and used as dummy variables. Thirdly, the subsidiary's local embeddedness may vary depending on the industry to which the subsidiary belongs. Labor intensive industries require a lot of labor but does not need a high level of technology, whereas technology and capitalintensive industries are more likely to need greater interactions with local networks. As dummy variables in this study, labor intensive industries were assigned 0 and technology and capital-intensive industries were assigned 1. Fourthly, we anticipated that the subsidiary's size may also affect its degree of local embeddedness and included this as a control variable.

\section{Analysis Results}

\subsection{Reliability and Validity Analysis}

<Table 1> shows the analysis results regarding the validity and reliability of this study. To verify the construct validity of the measured variables, we performed factor analysis, and applied varimax to maintain the independence of each factor. As seen in Table 1, the cumulative variance was $74.7 \%$ and all independent variables factors had high factor loading, confirming that the measurements of the study's independent variables were valid. Also, to verify the variables' reliability, we used Cronbach's Alpha, which is an indicator of internal consistency. Generally, if the Cronbach's Alpha value is 0.6 or more, the reliability is considered high and therefore we concluded that the variables in this study had no issues in reliability (Nunnaly, 1978).

Table 1: Varimax Rotated Factor Analysis Matrix

\begin{tabular}{|c|c|c|c|c|}
\hline Variable & Items & $\begin{array}{l}\text { Autonomy } \\
\text { (Factor1) }\end{array}$ & $\begin{array}{c}\text { Local } \\
\text { Embeddedness } \\
\text { (Factor2) }\end{array}$ & $\begin{array}{l}\text { Absorptive Capacity } \\
\text { (Factor3) }\end{array}$ \\
\hline \multirow[t]{6}{*}{ Autonomy } & Autonomy_2 & .934 & .178 & .050 \\
\hline & Autonomy_4 & .911 & .191 & -.059 \\
\hline & Autonomy_6 & .860 & .067 & -.013 \\
\hline & Autonomy_1 & .846 & .030 & .170 \\
\hline & Autonomy_5 & .816 & .087 & -.016 \\
\hline & Autonomy_3 & .722 & .369 & -.158 \\
\hline \multirow[t]{4}{*}{ Local Embeddedness } & Embeddedness_2 & .183 & .908 & .228 \\
\hline & Embeddedness_4 & .128 & .894 & .181 \\
\hline & Embeddedness_1 & .112 & .771 & .072 \\
\hline & Embeddedness_3 & .210 & .746 & .236 \\
\hline \multirow[t]{4}{*}{ Absorptive Capacity } & Acap_4 & .098 & .014 & .914 \\
\hline & Acap_3 & .017 & .144 & .805 \\
\hline & Acap_2 & -.074 & .333 & .781 \\
\hline & Acap_1 & -.053 & .175 & .733 \\
\hline Eigenvalue & & 4.467 & 3.156 & 2.838 \\
\hline$\%$ of Variance & & 31.907 & 22.54 & 20.271 \\
\hline Cumulative $\%$ & & 31.907 & 54.447 & 74.718 \\
\hline Cronbach's $\alpha$ & & .929 & .891 & .841 \\
\hline
\end{tabular}




\subsection{Reliability and Validity Analysis}

Table 2 presents the correlations between the variables used in this study and the descriptive statistics. The analysis results included variables with relatively high correlation coefficients, and therefore we examined the variance inflation factor (VIF). Generally, if the variance inflation factor has a value of 10 or more, there may be problems in the regression model caused by multi-collinearity (Neter et al., 1996). Since the highest variance inflation factor in our analysis results had a value of only 1.33 , we included all the variables in the regression model.

Table 2: Descriptive Statistics and Pearson Correlation Matrix

\begin{tabular}{|c|c|c|c|c|c|c|c|c|c|c|c|}
\hline Variables & Mean & SD & 1 & 2 & 3 & 4 & 5 & 6 & 7 & 8 & 9 \\
\hline 1. Local Embeddedness & 2.825 & .7451 & 1.000 & & & & & & & & \\
\hline 2. HQ's Global Capability & .819 & .7334 & .069 & 1.000 & & & & & & & \\
\hline 3. Autonomy & 2.611 & .8593 & $.340^{* * *}$ & .087 & 1.000 & & & & & & \\
\hline 4. Subsidiary Absorptive Capacity & 4.175 & .6799 & $.393^{* \star *}$ & -.100 & .029 & 1.000 & & & & & \\
\hline 5. Subsidiary's Staff Localization & 16.436 & 11.318 & $.583^{* * *}$ & $.144^{* *}$ & $.194^{* *}$ & $.348^{* * *+1}$ & 1.000 & & & & \\
\hline 6. Subsidiary Age & 10.263 & 4.747 & .004 & $-.235^{* *+1}$ & -.082 & .006 & -.035 & 1.000 & & & \\
\hline 7. Subsidiary Size & 6.844 & .828 & $.161^{* *}$ & -.113 & -.101 & $.126^{* *}$ & -.031 & .111 & 1.000 & & \\
\hline 8. Entry Mode & .842 & .366 & -.086 & -.069 & -.056 & -.101 & $-.131^{* *}$ & -.108 & -.064 & 1.000 & \\
\hline 9. Industry & .368 & .484 & -.101 & .101 & $.206^{* *}$ & -.104 & $-.229^{* * *}$ & -.073 & .030 & -.068 & 1.000 \\
\hline
\end{tabular}

\subsection{Multiple Regression Analysis Results}

$<$ Table 3> presents the results of the regression analysis performed to verify the hypotheses of this study. The analysis results can be summarized as follows. First, Hypothesis 1 was that when the headquarters grants a high degree of autonomy to a foreign subsidiary, this will have a positive influence on the local embeddedness of the foreign subsidiary. The analysis results for Model 2 and 3 which included the independent variables showed that the positive correlation between the autonomy of the subsidiary from the headquarters and local embeddedness was statistically significant at $\mathrm{p}<0.01$. Therefore, the results supported Hypothesis 1, that the level of autonomy of the foreign subsidiary from the headquarters has a positive influence on the foreign subsidiary's local embeddedness.

Hypothesis 2 anticipated that since headquarters with strong global capabilities will prioritize above all the goal of achieving global integration and efficiency by enabling the foreign subsidiaries to utilize the capabilities of the headquarters, such strong global capabilities will negatively affect the independent business activities of the subsidiary. The related analysis results did not show any statistical significance.

Hypothesis 3 posited that when the foreign subsidiary has a strong absorptive capacity, this will have a positive influence on the foreign subsidiary's local embeddedness. The analysis results showed that the foreign subsidiary's absorptive capacity and its local embeddedness had a positive $(+)$ correlation at $\mathrm{p}<0.01$. These results confirmed that when the foreign subsidiary has strong absorptive capacity in the locality, this will have a positive effect on its embeddedness in the local network.

Hypothesis 4 claimed that when the foreign subsidiary achieves a high level of staff localization, this will positively affect the foreign subsidiary's local embeddedness. The analysis results indicated that the foreign subsidiary's staff localization and its local embeddedness had a positive $(+)$ correlation at $\mathrm{p}<0.01$. This demonstrated that when a foreign subsidiary has more staff localization, this positively affects the foreign subsidiary's local network embeddedness.

Table 3: Results of Regression Analysis for Testing $\mathrm{H} 1-\mathrm{H} 4$

\begin{tabular}{|c|c|c|c|c|}
\hline Variables & VIFs & Model 1 & Model 2 & Model 3 \\
\hline \multicolumn{5}{|l|}{ Control variables } \\
\hline Entry Mode & 1.057 & $\begin{array}{r}-.920 \\
(0.360) \\
\end{array}$ & $\begin{array}{r}-.656 \\
(0.513)\end{array}$ & $\begin{array}{r}.327 \\
(.744)\end{array}$ \\
\hline |ndustry & 1.169 & $\begin{array}{l}-1.214 \\
(0.227)\end{array}$ & $\begin{array}{r}-2.235 \\
(.027)\end{array}$ & $\begin{array}{r}-.477 \\
(.634)\end{array}$ \\
\hline Subsidiary Size & 1.054 & $\begin{array}{r}1.718 \\
(0.089)\end{array}$ & $\begin{array}{r}2.386^{*} \\
(.019)\end{array}$ & $\begin{array}{l}2.470 \\
(.015)\end{array}$ \\
\hline Subsidiary age & 1.092 & $\begin{array}{r}-0.33 \\
(0.742) \\
\end{array}$ & $\begin{array}{l}.118 \\
(.906)\end{array}$ & $\begin{array}{r}.391 \\
(.696)\end{array}$ \\
\hline \multicolumn{5}{|l|}{ Independent variables } \\
\hline \multicolumn{5}{|l|}{ HQ Level } \\
\hline HQ's Global Capability & 1.138 & & $\begin{array}{r}.856 \\
(.394)\end{array}$ & $\begin{array}{r}.434 \\
(.665) \\
\end{array}$ \\
\hline HQ's Autonomy & 1.132 & & $\begin{array}{r}4.399^{*+1} \\
(.001)\end{array}$ & $\begin{array}{r}3.611 \\
(.001)\end{array}$ \\
\hline \multicolumn{5}{|l|}{ Subsidiary Level } \\
\hline $\begin{array}{|ll|}\text { Subsidiary } & \text { Absorptive } \\
\text { Capacity } & \end{array}$ & 1.196 & & & $\begin{array}{r}2.655^{\mathrm{m}} \\
(.009)\end{array}$ \\
\hline \begin{tabular}{|l|} 
Subsidiary's \\
Staff Localization
\end{tabular} & 1.339 & & & $\begin{array}{r}5.551 \\
(.000) \\
\end{array}$ \\
\hline Adj. R Square & & 0.01 & 0.153 & 0.432 \\
\hline F-Stat. & & 1.28 & 4.403 & 11.737 \\
\hline $\mathrm{N}$ & & 114 & 114 & 114 \\
\hline
\end{tabular}

\section{Discussion and conclusion}

This study performed an empirical analysis of the factors related to a multinational corporation's headquarters and its subsidiaries that influence the local network embeddedness of the foreign subsidiaries, by analyzing the survey responses collected from 114 subsidiaries of South Korean corporations active in China.

The main conclusions drawn from the study's results are as follows.

First, the empirical analysis confirmed that when the headquarters gives the foreign subsidiary more autonomy, 
this has a positive effect on the local embeddedness of the foreign subsidiary. Our empirical analysis verified the truth of the argument that when the headquarters exercises strong control over the foreign subsidiary, this restricts the subsidiary's ability to actively accumulate local knowledge and experience, which may stunt the growth of the subsidiary, and obstructs the subsidiary from freely engaging in exploration and experimentation and thus forming a new network in the local market. Our findings support the claims of preceding studies that while the foreign subsidiary needs to actively explore and experiment in the local network to reduce its cost of foreignness, the high level of control imposed by the headquarters may decrease learning motivation and experimental initiative (Frost et al., 2002).

Secondly, we predicted that when a multinational corporation has a lot of internationalization experience in various foreign markets, this will likely negatively affect the independent business activities of the subsidiary and consequently harm the subsidiary's motivation to actively interact with the various local networks. Our empirical analysis results, however, did not indicate any significant correlation between the global capabilities of the headquarters and the local embeddedness of the foreign subsidiary.

Thirdly, we found that when the foreign subsidiary has a strong absorptive capacity, this has a positive correlation with the local embeddedness of the foreign subsidiary. Our empirical analysis proved that if the foreign subsidiary has a strong absorptive capacity, it will be able to extract and internalize valuable knowledge and information from the diversified knowledge flow that exists in the foreign market. Furthermore, it will be able to efficiently absorb and digest the knowledge transferred from its headquarters. In this process, the subsidiary will become more motivated to actively seek information exchange with various local network and will therefore strengthen relations with the local network.

Fourthly, we found that when the foreign subsidiary has achieved a high level of staff localization, this foreign subsidiary will have a higher level of local embeddedness. Localization can be understood as the process in which a corporation that engages in international business activities seeks to improve its competitive superiority by adapting to the different culture or business environment found in the country it has entered. The subsidiary will focus on reconstructing its strategic and managerial decision-making processes in response to local conditions, taking account of the various cultural, environmental characteristics of the locality. Staff localization is very important for achieving this goal. Local staff members tend to more actively form relations with local networks in their business activities and facilitate communication with local stakeholders. We predicted that consequently, staff localization will have a positive effect on local network embeddedness, and this hypothesis was supported by our empirical analysis.
Synthesizing our empirical analysis results, it can be concluded that our findings support our overall thesis: local network embeddedness, which plays a key role in the survival and growth of a foreign subsidiary in the local market, is influenced by complex factors related to the multinational corporation's headquarters and their subsidiaries and is not simply determined by one specific factor.

This study has the following scholarly and practical implications.

First, in contrast to previous studies which adopted the network embeddedness of a multinational corporation as their independent variable and focused on the results, this study is significant because it used the degree network of embeddedness as a dependent variable. More specifically, most preceding studies argued that the level of local network embeddedness achieved by the foreign subsidiary of a multinational corporation is an antecedent factor that affects variables such as the corporation's financial performance, degree of knowledge transfer, and level of innovation. However, despite this importance of local network embeddedness to the multinational corporation, there were very few studies that examined the factors that determine local network embeddedness. This study identified the preceding conditions necessary for a foreign subsidiary of a multinational corporation to effectively embed itself in the local network by analyzing factors related to the multinational corporation's headquarters and subsidiaries, and thus contributes significantly to continued research on the local embeddedness of subsidiaries.

Secondly, one practical implication of this study is that managers at the headquarters should help improve local network embeddedness by avoiding excessive control over its subsidiaries and instead granting enough autonomy so that foreign subsidiaries will find conditions conducive for actively embedding themselves in the local network. One of the best methods of offsetting the cost of foreignness that subsidiaries incur upon entry into a foreign market is to engage in business activities closely embedded in the local network. With greater autonomy, the managers of the subsidiary will be able to foster and develop the firm's knowledge absorptive capacity and enhance its local network embeddedness. In addition, implementing staff localization in the foreign subsidiary can help strengthen local network embeddedness.

While this study contributed these scholarly and practical insights, the following limitations of this study remains to be addressed. First, because this study replied on survey responses collected from a single respondent selected from South Korean managerial staff at foreign subsidiaries, we cannot preclude the possibility that subjective judgments of respondents may have distorted the analysis results. To redress this, we will need to build a more robust set of data by collecting survey responses from multiple staff members in the targeted firms. Secondly, this study only measured staff localization as an indicator of the level of localization. In follow-up studies, it will be necessary to consider other 
factors such as product localization, or the localization of parts procurement, since localization is multi-layered concept.

\section{References}

Ahuja, G. (2000). Collaboration networks, structural holes, and innovation: A longitudinal study. Administrative Science Quarterly, 45(3), 425-455.

Ahuja, G. (2000). The duality of collaboration: Inducements and opportunities in the formation of interfirm linkages. Strategic Management Journal, 21(3), 317-343.

Andersson, U., \& Forsgren, M. (2000). In search of centre of excellence: Network embeddedness and subsidiary roles in multinational corporations. Management International Review, 40(4), 329-350.

Andersson, U., Björkman, I., \& Forsgren, M. (2005). Managing subsidiary knowledge creation: The effect of control mechanisms on subsidiary local embeddedness. International Business Review, 14(5), 521-538.

Andersson, U., Forsgren, M., \& Holm, U. (2001). Subsidiary embeddedness and competence development in MNCs: A multi-level analysis. Organization Studies, 22(6), 1013-1034.

Andersson, U., Forsgren, M., \& Holm, U. (2002). The strategic impact of external networks: Subsidiary performance and competence development in the multinational corporation. Strategic Management Journal, 23(11), 979-996.

Baum, J. A. C., \& Oliver, C. (1991). Institutional linkages and organizational mortality. Administrative Science Quarterly, 36(2), 187-218.

Birkinshaw, J., \& Hood, N. (1998). Multinational subsidiary evolution: Capability and charter change in foreignowned subsidiary companies. Academy of Management Review, 23(4), 773-795.

Birkinshaw, J., Hood, N., \& Jonsson, S. (1998), Building firm specific advantages in the role of subsidiary initiative. Strategic Management Journal, 19(3), 221242.

Ciabuschi, F., Holm, U., \& Martín, O. M. (2014). Dual embeddedness, influence and performance of innovating subsidiaries in the multinational corporation. International Business Review, 23(5), 897-909.

Cohen, W., \& Levinthal, D. A. (1990). Absorptive capacity: A new perspective on learning and innovation. Administrative Science Quarterly, 35(1), 128-152.

Dayasindhu, N. (2001). Embeddedness, knowledge transfer, industry clusters and global competitiveness: A case study of the Indian software industry. Technovation, 22(9), 1-10.

Dhanaraj, C., Lyles, M. A. Steensma, H. K., \& Tihanyi, L. (2004). Managing tacit and explicit knowledge transfer in IJVs: The role of relational embeddedness and the impact on performance. Journal of International Business Studies, 35(5), 428-442.
Dore, R. (1992). The sociology of economic life. Colorado, MA: Westview Press.

Doz, Y., \& Prahalad, C. K. (1981). Headquarters influence and strategic control in MNCs. Sloan Management Review, 23(1), 15-29.

Doz, Y., Bartlett, C., \& Prahalad, C. K. (1981). Global competitive pressures and host country demands. California Management Review, 23(3), 63-74.

Egelhoff, W. G. (1988). Organizing the multinational enterprise: An information-processing perspective. Cambridge, MA: Ballinger Publishing Company.

Frost, T. S., Birkinshaw J. M., \& Ensign, P. C. (2002), Centers of excellence in multinational corporations. Strategic Management Journal, 23(11), 997-1018.

Gates, S. R., \& Egelhoff, W. G. (1986) Centralization in headquaters-subsidiary relationships. Journal of International Business Studies, 17(2), 71-92.

Ghoshal, S., Korine, H., \& Szulanski, G. (1994). Interunit communication in multinational corporations. Management Science, 40(1), 96-110.

Gong, Y. (2003). Subsidiary staffing in multinational enterprises: Agency, resources, and performance. Academy of Management Journal, 46(6), 728-739.

Grabher, G. (1993). Rediscovering the social in the economics of interfirm relations. In G. Grabher, The embedded firm (pp.1-31), London, UK: Routledge Press.

Granovetter, M. (1985). Economic action and social structure: The problem of embeddedness. American Journal of Sociology, 91(2), 481-487.

Granovetter, M. (1992). Problems of explanation in economic sociology. In N. Nohria, \& R. G. Eccles, Networks and organizations: Structure, form and action (pp.50-77), Boston, Massachusett: Harvard Business School Press.

Gulati, R. (1998). Alliance and networks. Strategic Management Journal, 19(4), 293-317.

Gupta, A. K., \& Govindarajan, V. (1991). Knowledge flows and the structure of control within multinational corporations. Academy of Management Review, 16(4), 768-792.

Gupta, A. K., \& Govindarajan, V. (2000). Knowledge flows within multinational corporations. Strategic Management Journal, 21(4), 473- 496.

Hagedoorn, J., \& Schakenraad, J. (1994). The effect of strategic technology alliances on company performance. Strategic Management Journal, 15(4), 291-309.

Halien, A., \& Tornroos, J. A. (1998). The role of embeddedness in the evolution of business networks. Scandinavian Journal of Management, 14(3), 194-196.

Jeong, D., \& Wan, Q. (2016). Evaluation on development performances of E-Commerce for 50 major cities in China. Journal of Distribution Science, 14(1), 67-74.

Jones, C., Hesterly, W. S., \& Borgatti, S. P. (1997). A general theory of network governance: Exchange conditions and social mechanism. Academy of Management Review, 22(4), 912-913.

Joseph, C. S., Chen, T. Y., \& Yang, P. Y. (2016). Local 
embeddedness, market focus, and productivity: Evidence of Taiwanese manufacturing MNE subsidiaries in China. Growth \& Change, 47(4), 596-611.

Kim, M. (2018), The role of structural holes in uncertain environments in channel relationships. Journal of Distribution Science, 16(6), 25-35.

Kogut. B., \& Zander, U. (1993). Knowledge of the firm, and the evolutionary theory of the multinational corporation. Journal of International Business Studies, 24(4), 625645.

Lam, S. K., \& Yeung, C. K. (2010). Staff localization and environmental uncertainty on firm performance in China. Asia Pacific Journal of Management, 27(4), 677-695.

Liao, S. (2015). Applying the product design of learning and management for innovation development. Journal of Distribution Science, 13(6), 22-33.

Li, H. Y., \& Zhang, Y. (2007). The role of mangers' political network and functional experience in new venture performance: Evidence from China's. Strategic Management Journal, 28(8), 791-804.

Luo, Y., Shenkar, O., \& Nyaw, M. K. (2002). Mitigating liabilities of foreignness: Defensive versus offensive approaches. Journal of International Management, 8(3), 283-300.

Martynovich, M. (2017). The role of local embeddedness and non-local knowledge in entrepreneurial activity. Small Business Economics, 49(4), 741-762.

McEvily, B., \& Zaheer, A. (1999). Bridging ties: A source of firm heterogeneity in competitive capabilities. Strategic Management Journal, 20(12), 1133-1156.

Minbaeva, D., Pedersen, T, Bjorkman, I., Fey, C. F., \& Park, H. J. (2014). MNC knowledge transfer, subsidiary absorptive capacity, and HRM. Journal of International Business Studies, 45(1), 38-51.

Miner, A. S., Amburgey, T. L., \& Stearns, T. (1990). Interorganizational linkages and population dynamics: Buffering and transformational shields. Administrative Science Quarterly, 3(5), 689-713.

Perlmutter, H. V. (1969). Tortuous evolution of the multinational corporation. Columbia Journal of World
Business, 4(1), 9-18.

Powell, W. (1990). Neither market nor hierarchy: Network forms of organization. Research in Organizational Behaviour, 12(1), 295-336.

Prahalad, C. K., \& Doz, Y. L. (1987). The multinational mission: Balancing global integration with local responsiveness. New York, MA: FreePress.

Rosenzweig, M., \& Nohria, N. (1994). Influence of human resource management practice in multinational corporations. Journal of International Business Studies, 25(2), 229-251.

Song, J. Y. (2002). Firm capabilities and technology ladders: Sequential foreign direct investments of Japanese electronics firms in East Asia. Strategic Management Journal, 23(3), 191-210.

Sumelius, J., \& Sarala, R. (2008). Knowledge development in MNC subsidiaries: The influence of MNC internal and external knowledge and control mechanisms. Thunderbird International Business Review, 50(4), 245258.

Takeuchi, R., Shay, J. P., \& Li, J. (2008). When does decision autonomy increase expatriate managers' adjustment? An empirical test. Academy of Management Journal, 51(1), 45-60.

Tichy, N. M., Tushman, M. L., \& Fomburn, C. (1979). Social network analysis for organizations. Academy of Management Review, 4(4), 507-519.

Tsai, W., \& Ghoshal, S. (1998). Social capital and value creation: The role of the intrafirm networks, Academy of Management Journal, 41(4), 464-476.

Wei, Y. H. (2015). Network linkages and local embeddedness of foreign ventures in China: The case of Suzhou municipality. Regional Studies, 49(2), 287-299.

Young, S., \& Tavares, A. T. (2004). Centralization and autonomy: Back to the future. International Business Review, 13(2), 215-237.

Zaheer, A., \& Zaheer, S. (1997). Catching the wave: Alertness, responsiveness and market influence in global electronic networks. Management Science, 43(11), 1493 1509 . 